\title{
Design of Information Systems for Research Permit Application with Agile Method and Website Based Laravel Framework
}

\section{Perancangan Sistem Informasi Permohonan Perizinan Penelitian dengan Metode Agile dan Framework Laravel Berbasis Website}

\author{
Steven Hendrawan ${ }^{1}$, Augie David Manuputty ${ }^{2}$, Budi Haryanto ${ }^{3}$ \\ 1,2Program Studi S1 Sistem Informasi, Universitas Kristen Satya Wacana, Salatiga, Indonesia \\ ${ }^{3}$ Dinas Komunikasi dan Informatika, Salatiga, Indonesia \\ Email:1682015005@student.uksw.edu,2augie.manuputty@uksw.edu, \\ 3budi.haryanto@salatiga.go.id
}

\begin{abstract}
Era sekarang adalah era digital, hampir semua orang menggunakan teknologi untuk mendukung aktivitas sehari-hari. Pemerintah Kota Salatiga merupakan salah satu bagian yang memerlukan teknologi untuk mendukung pekerjaan yang dilakukan, terkhusus di bagian pengelolaan data permohonan kerja praktek, pengambilan data dan survei. Terdapat kesulitan yang dialami oleb operator yang bertugas untuk mengelola permohonan penelitian yang diajukan pemohon. Kesulitan yang dialami adalab melakukan record data permohonan berkelompok dan laporan mengenai permohonan tersebut. Peneliti dibantu Bapak Budi Haryanto menyelesaikan permasalahan yang ada dengan membuat website pengelolaan permohonan penelitian. Tidak hanya untuk mengatasi permasalaban yang ada, Website dibuat untuk mendukung pengelolaan permohonan penelitian. Peneliti menggunakan metode perancangan Agile dan framework Laravel dalam pembuatan website. Untuk menggambarkan kebutuban pengguna, peneliti menggunakan Unified Modelling Language (UML). Pengujian aplikasi dilakukan dengan menggunakan metode White Box Testing. In this digital era, almost all people using technology to support their work. The government of Salatiga is one of organization that need technology to support their work, especially in manage data of internship, observation and survey request section. There are two main problems for operator in this section. First, operator get difficult to record data of group request and second, to make a report. Researcher helped by Mr. Budi Haryanto solved those problem with website that we built. The purpose of this website are not only to solve problems that occurred but also supported operator to manage research request. Researcher used Agile development system and Laravel Framework for built website. To describe users'need, researcher used Unified Modelling Language (UML). To test the application, researcher used White Box Testing method.
\end{abstract}

Keywords: Laravel, Waterfall, Unified Modelling Language, Data Flow Diagram, White Box Testing, Framework. 


\section{INTRODUCTION}

Badan Kesatuan Bangsa dan Politik (Bakesbangpol) Pemerintah Kota Salatiga adalah salah satu badan pemerintah yang ada di Pemerintah Kota Salatiga, dengan beberapa tugas pokok dan fungsi sesuai peraturan pemerintah. Terdapat beberapa bidang di Bakesbangpol, salah satunya adalah kewaspadaan nasional, dimana tugas pokok bidang kewaspadaan nasional adalah membuat kebijakan dan mengawasi serta mengevaluasi pelaksanaan kebijakan tersebut. Ruang lingkup kewaspadaan nasional dalam membuat kebijakan yaitu kewaspadaan dini, penanganan konflik pemerintahan, penanganan konflik sosial serta pengawasan orang asing dan lembaga asing. Fungsi keenam kewaspadaan nasional adalah mengoordinasi dan memfasilitasi pembinaan penyelenggaraan pemerintahan dalam bidang ketahanan seni dan budaya, agama dan kepercayaan, pembauran dan akulturasi budaya, organisasi kemasyarakatan serta penanganan masalah sosia

1 kemasyarakatan skala kota. Kewaspadaan nasional memiliki tugas untuk mengurus permohonan perizinan penelitian di Pemerintah Kota Salatiga. Penelitian dalam sistem operasional Bakesbangpol meliputi kerja praktek, pengambilan data dan survei. [1]

Proses permohonan perizinan penelitian di Bakesbangpol Pemerintah Kota Salatiga adalah proses yang dijalankan oleh pengguna untuk menghasilkan surat permohonan izin penelitian yang digunakan oleh pemohon sebagai syarat untuk melakukan penelitian. Dalam menjalankan perizinan, pihak Kesbangpol tidak memiliki media khusus untuk melakukan komunikasi dengan pemohon sehingga ketika memiliki persoalan, operator menghubungi pemohon menggunakan Whats App (WA) pribadi. Jika terdapat permasalahan mengenai berkas yang tidak sesuai ketentuan atau tidak lengkap, maka pemohon harus datang lagi ke lokasi untuk menyerahkan berkas yang sudah disiapkan lagi oleh pemohon. Dalam proses permohonan perizinan penelitian ini, operator mengalami kendala dalam menyimpan data serta membuat laporan. Kendala operator dalam penyimpanan data disebabkan media penyimpanan data tidak memberikan operator kemudahan dalam menyimpan data dalam jumlah banyak, seperti informasi permohonan dari pemohon berkelompok.

Teknologi informasi (TI) merupakan salah satu media yang dapat dimanfaatkan untuk menyelesaikan persoalan tersebut. Dengan menggunakan TI, operator dapat memberikan informasi mengenai berkas yang harus diserahkan kepada pihak Bakesbangpol bahkan informasi mengenai permohonan ketika permohonan tersebut sedang diproses, sehingga pemohon tidak perlu datang ke lokasi untuk memperoleh informasi tersebut. TI membantu operator dalam menyimpan informasi permohonan. Aplikasi akan melakukan penyimpanan informasi pemohonan secara otomatis. Informasi permohonan yang disimpan, seperti waktu pengarsipan data, judul data dan id pemohon. Selain itu, TI juga membantu operator dalam pembuatan laporan. Aplikasi akan membuat laporan sesuai kategori yang dibutuhkan operator, seperti laporan mengenai jumlah pemohon 
dalam kurun waktu satu minggu, lokasi yang sering dijadikan obyek penelitian atau jenis penelitian yang sering dilakukan pemohon maupun organisasi.

TI memungkinkan penambahan proses bisnis dan aktor pada proses permohonan perizinan penelitian. Proses bisnis tersebut ditambahkan untuk membantu pengguna dalam menjalankan proses permohonan perizinan penelitian. Proses bisnis tersebut akan dijelaskan lebih mendalam dalam bab hasil dan pembahasan. TI juga menambahkan satu aktor pengguna yaitu administrator. Administrator memiliki tugas mengawasi dan mengontrol aktivitas yang dilakukan oleh operator dan pemohon sehingga jika terjadi permasalahan dalam melaksanakan proses permohonan perizinan penelitian, administrator dapat mengecek aktivitas yang dilakukan operator dan pemohon untuk mengatasi permasalahan tersebut. Aktivitas-aktivitas yang telah dilakukan oleh operator dan pengguna juga dapat dijadikan bahan evaluasi agar proses permohonan perizinan penelitian dapat dilakukan lebih tepat dan cepat.

Oleh karena persoalan-persoalan dalam proses permohonan perizinan penelitian yang terjadi di Bakesbangpol Pemerintah Kota Salatiga dan perintah yang diberikan oleh Pak Budi Haryanto selaku penanggung jawab peneliti di tempat peneliti kerja praktek, maka peneliti meneliti permasalahan tersebut dan berupaya menyelesaikan permasalahan tersebut. Penelitian dilakukan dalam lingkup permohonan perizinan penelitian. Peneliti menyelesaikan permasalahan yang ada di Bakesbangpol dengan membuat aplikasi berbasis website.

Peneliti menggunakan beberapa penelitian terdahulu sebagai referensi untuk penelitian ini dengan harapan dapat memperbaiki dan mengembangkan penelitian yang sudah dilakukan terlebih dulu. Peneliti mengambil tiga penelitian terdahulu. Penelitian-penelitian tersebut memiliki karakteristik yang berbeda dengan penelitian yang dilakukan peneliti.

Penelitian pertama yang peneliti jadikan referensi dilakukan oleh Adri Dazi Hermandra dan Anofrizen (2016) dengan judul Pengembangan Sistem Informasi Kerja Praktek (Studi Kasus: Jurusan Sistem Informasi UIN SUSKA Riau). Sistem ini tidak hanya berfokus pada penyelesaian masalah yang ada, tetapi juga memperhatikan tampilan aplikasi. Framework yang digunakan untuk membangun aplikasi tersebut adalah Prototype. Aplikasi yang dibangun peneliti menggunakan framework Laravel.

Penelitian yang lain dilakukan oleh Candra Aji Pamungkas dengan judul Sistem Informasi Kerja Praktek FTI UKSW Berbasis Website dengan Framework CodeIgniter. Aplikasi tersebut menghasilkan output surat pengantar, form nilai dan arsip data mahasiswa yang mengambil matakuliah kerja praktek. Framework, atau metode perancangan yang digunakan dalam pembuatan website yaitu CodeIgniter. Penelitian selanjutnya dilakukan oleh Tunggul Adi Bisono dkk. dengan judul Perancangan Sistem Pendaftaran Pasien Rawat Jalan Rumah Sakit Melalui Short Message Service Gateway (Studi Kasus: RS. Panti Wilasa "Dr. Cipto" Semarang). Aplikasi tidak hanya digunakan sebagai alat registrasi tetapi juga pemberi informasi 
kepada pasien. Aplikasi ini menggunakan basis Short Message Service (SMS) dalam memberikan informasi kepada pasien.

Penelitian ini memiliki perbedaan dan persamaan dengan ketiga penelitian yang terdahulu. Dalam penelitian pertama, penelitian ini memiliki persamaan dalam fokus penggunaan aplikasi, yaitu tidak hanya untuk menyelesaikan masalahmasalah yang ada, tetapi juga memperhatikan tampilan bagi pengguna. Perbedaan dengan penelitian ini adalah metode perancangan sistem yang digunakan. Dalam penelitian tersebut menggunakan metode Prototype, sedangkan peneliti menggunakan metode Agile. Dalam penelitian kedua, output aplikasi yang dihasilkan mirip dengan output aplikasi yang peneliti buat, yaitu surat pengantar dan data mahasiswa yang mendaftar kerja praktek. Bagian yang membedakan dengan penelitian ini adalah output form nilai yang tidak peneliti gunakan dan cakupan pengguna aplikasi. Aplikasi tersebut digunakan untuk pendaftaran mahasiswa saja, sedangkan aplikasi yang peneliti buat mencakup mahasiswa dan organisasi. Framework yang digunakan juga berbeda. Peneliti menggunakan framework pembuatan aplikasi yang bernama Laravel, sedangkan penelitian tersebut menggunakan framework CodeIgniter. Dalam penelitian yang ketiga, memiliki perbedaan dalam metode pengiriman informasi. Dalam penelitian tersebut, metode pengiriman informasi menggunakan SMS. Sedangkan peneliti menggunakan email. Namun, penelitian ini memiliki persamaan dalam penggunaan aplikasi, yaitu tidak hanya sebagai alat registrasi tetapi juga pemberi informasi. Penelitian ini dilakukan untuk menyelesaikan permasalahan yang ada di Bakesbangpol dan memperkaya pengetahuan kita mengenai metode perancangan yang digunakan untuk membuat aplikasi.

Sistem Informasi (SI) melibatkan manusia dan teknologi. SI digunakan oleh organisasi maupun individu untuk mencapai tujuan yang diharapkan. Berikut adalah beberapa pendapat mengenai SI menurut beberapa ahli. Menurut Laudon dan Laudon (2018), sistem informasi adalah sekumpulan komponen yang berfungsi mengumpulkan, menyimpan, dan mengolah data dan bertujuan untuk memberi informasi, pengetahuan, dan produk digital, saling bekerja sama untuk mencapai suatu tujuan. [2] Menurut Tata Sutabri dan Darmawan Napitupulu dalam bukunya mengatakan sistem informasi adalah suatu sistem yang mendukung proses bisnis organisasi dalam tingkat manajerial dengan membuat strategi dari pengolahan data transaksi harian kepada pihak luar tertentu dalam bentuk laporan. [3] Menurut Gordon B.Davis, sistem informasi merupakan jalinan terintegrasi antara manusia dan atau mesin untuk menyajikan informasi yang dibutuhkan oleh pengambil keputusan. [4]

Perizinan adalah salah satu proses yang terdapat dalam sistem ini. Perizinan diperlukan dalam sistem ini agar menjaga keteraturan penggunaan sistem dan keamanan data. Berikut pendapat mengenai perizinan menurut para ahli: Menurut I Made Arya Utama, penetapan perizinan sebagai salah satu instrumen hukum dari pemerintah yaitu untuk mengendalikan kehidupan masyarakat agar tidak menyimpang dari ketentuan hukum yang berlaku serta membatasi aktifitas 
masyarakat agar tidak merugikan orang lain. Dengan demikian, perizinan lebih merupakan instrumen pencegahan atau berkarakter sebagai preventif instrumental. [5] Menurut Sjachran Basah, perizinan adalah perbuatan hukum Negara yang bersegi satu yang mengaplikasikan peraturan dalam hal konkreto berdasarkan persyaratan dan prosedur sebagaimana ditetapkan oleh ketentuan perundangundangan yang berlaku. Menurut N.M. Spelt dan J.B.J.M ten Berge, perizinan dalam arti sempit adalah pembuat undang-undang untuk mencapai suatu tatanan tertentu atau untuk menghalangi keadaan-keadaan yang buruk. [6]

Website sangat sering digunakan di kalangan masyarakat. Dalam hal ini, peneliti membuat aplikasi berbasis website. Berikut beberapa pendapat mengenai website menurut para ahli: Menurut Rohi Abdulloh (2018) dalam bukunya, mengatakan website adalah sekumpulan halaman yang berisi data digital, seperti teks, gambar, suara, video atau gabungan dari semua hal itu, yang dapat diakses oleh semua orang melalui jalur internet. [7] Menurut Jasmadi, website adalah kumpulan halamanhalaman web beserta file-file pendukungnya, seperti gambar, video, dan file digital lainnya yang diletakkan di host atau web server yang umumnya diakses melalui internet. Menurut Ali Zaki \& Smitdev Community, website adalah beberapa kumpulan dari halaman web yang terdapat pada satu domain, yang terdiri dari dua atau lebih halaman web. [8]

Laravel merupakan framework yang digunakan dalam pembuatan website. Laravel meringkas kode program karena beberapa baris kode yang digunakan dalam $p h p$, diringkas dalam Laravel. Selain itu, Developer juga tidak perlu menuliskan kode yang sama untuk digunakan. Cukup mengaturnya di controller, hal ini membuat kode lebih ringkas. Karena Laravel membuat kode yang lebih ringkas dan beberapa modul yang diberikan kepada developer dalam pengembangan website, maka waktu yang diperlukan untuk pembuatan website ini lebih cepat. Contoh modul yang diberikan adalah artisan, authentication dan controller.

Laravel membuat lebih hemat biaya dan waktu. Framework ini terhitung lebih hemat biaya dibandingkan framework lainnya. Laravel juga mudah dikembangkan, karena aturan-aturan yang ada dalam Laravel, maka memudahkan pengembang lain yang akan mengembangkan website tersebut. Laravel juga memiliki dokumentasi yang lengkap. Dokumen Laravel bisa diakses di id-laravel.com, learninglaravel.net, laracast.com dan Laravel-news.com. User Friendly merupakan kelebihan Laravel. Laravel dapat digunakan dengan mudah. Sehingga framework ini dikatakan user friendly. Selain itu, keamanan Laravel terjamin. Laravel memberi jaminan akan keamanan dari framework ini. Selain itu, ada juga komunitas Laravel. Penyelesaian masalah berkaitan dengan penggunaan Laravel terbilang banyak dan mudah ditemukan. Laravel mensupport metode MVC. MVC merupakan metode yang paling sering digunakan dalam penggunaan website saat ini. Laravel menggunakan metode MVC, sehingga memudahkan untuk pengembangan website. [9] Dalam penelitian ini, Laravel digunakan sebagai back-end.

Bootstrap merupakan pilihan bagi beberapa developer dalam membuat website. Berikut adalah beberapa pendapat mengenai bootstrap menurut para ahli: Menurut 
Heru Sulistiono (2018) dalam buku yang dia tulis, mengatakan bootstrap adalah sebuah framework CSS dan JavaScript yang digunakan untuk membuat website lebih responsif. [10] Menurut Roberto Kaban, pembuatan website lebih mudah karena aturan-aturan bootstrap yang sudah ditetapkan secara umum. [11]

\section{METHODS}

Dalam penelitian ini, peneliti menggunakan metode penelitian kualitatif. Peneliti menggunakan metode penelitian kualitatif karena metode ini mendukung peneliti untuk mendapatkan data yang dibutuhkan. Kecocokan metode ini terhadap penelitian yang peneliti lakukan akan dijelaskan lebih rinci melalui penjelasan mengenai pengertian, karakteristik serta tujuan metode ini pada paragraf selanjutnya. Untuk pengumpulan data, peneliti menggunakan teknik wawancara. Peneliti melakukan wawancara dengan pihak operator dan sekretariat di Bakesbangpol.

Peneliti membutuhkan informasi berupa pandangan secara khusus dari setiap orang yang berada dalam kondisi atau permasalahan yang terjadi. Penelitian kualitatif dapat menjawab kebutuhan tersebut. Hal tersebut dapat dilihat dari beberapa pengertian metode penelitian kualitatif menurut ahli. Menurut Denzin dan Lincoln (1994), penelitian kualitatif adalah penelitian yang dilakukan untuk menyelidiki fenomena secara alamiah dengan menggunakan metode yang ada. Menurut Erickson (1968), penelitian kualitatif adalah penelitian untuk menemukan dan menggambarkan secara naratif kegiatan yang dilakukan dan dampak yang terjadi terhadap mereka. [12]

Penelitian kualitatif memiliki karakteristik. Fitrah dan Luthfiyah menyimpulkan ada empat karakteristik penelitian kualitatif. Pertama, penelitian kualitatif setuju jika kasus yang terjadi adalah hasil dari pilihan setiap individu. Kedua, penelitian ini berfokus pada proses bukan hasil, sehingga peneliti mendapat posisi sebagai instrumen kunci utama pengumpul data. Dengan keterlibatan peneliti, hasil dapat dipertanggungjawabkan. Keempat, hasil yang diperoleh dapat digunakan untuk membantu masyarakat yang bersangkutan dengan tidak bertentangan nilai-nilai yang ada di masyarakat tersebut. Tujuan dari penelitian kualitatif adalah menghasilkan sebuah teori, merumuskan konsep dan menggambarkan pribadi individu ataupun kelompok. (Bogdand \& Biklen, 1998)

Menurut Johnson (2005) dan Creswell (2011), penelitian kualitatif dibagi menjadi beberapa jenis yaitu phenomenology, ethnography, case study research, grounded theory, dan historical research. [13] Peneliti menggunakan jenis penelitian studi kasus. Oleh karena itu, peneliti hanya akan menjelaskan jenis penelitian ini. Studi kasus termasuk dalam jenis pendekatan deskriptif, maksudnya penelitian ini dilakukan secara cermat hingga kasus terselesaikan. (Sutedi, 2009:61). Penelitian ini dilakukan dengan berfokus pada satu subyek atau obyek yang diteliti. Informasi terkait subyek atau obyek dapat diperoleh dari lingkungan sekitar subyek atau obyek tersebut. (Nanawi, 2003). Penelitian ini mempelajari latar belakang kondisi 
atau peristiwa yang telah terjadi atau sedang berlangsung, termasuk interaksi di lingkungan kondisi atau peristiwa tersebut tanpa direkayasa. Subyek dapat berupa individu ataupun kelompok. (Danim, 2002) [14]

Teknik pengumpulan data yang peneliti gunakan adalah wawancara informal. Wawancara informal lebih menekankan kepada pewawancara dalam keberhasilan wawancara. Percakapan antara pewawancara dan narasumber berlangsung seperti percakapan sehari-hari. (Patton 1980 : 197) [15]

\subsection{Research Methods}

Dalam melakukan penelitian, peneliti melakukan beberapa tahapan. Tahapan penelitian ini dilakukan untuk mengetahui serta memecahkan masalah yang ada. Berikut adalah tahapan yang peneliti lakukan:

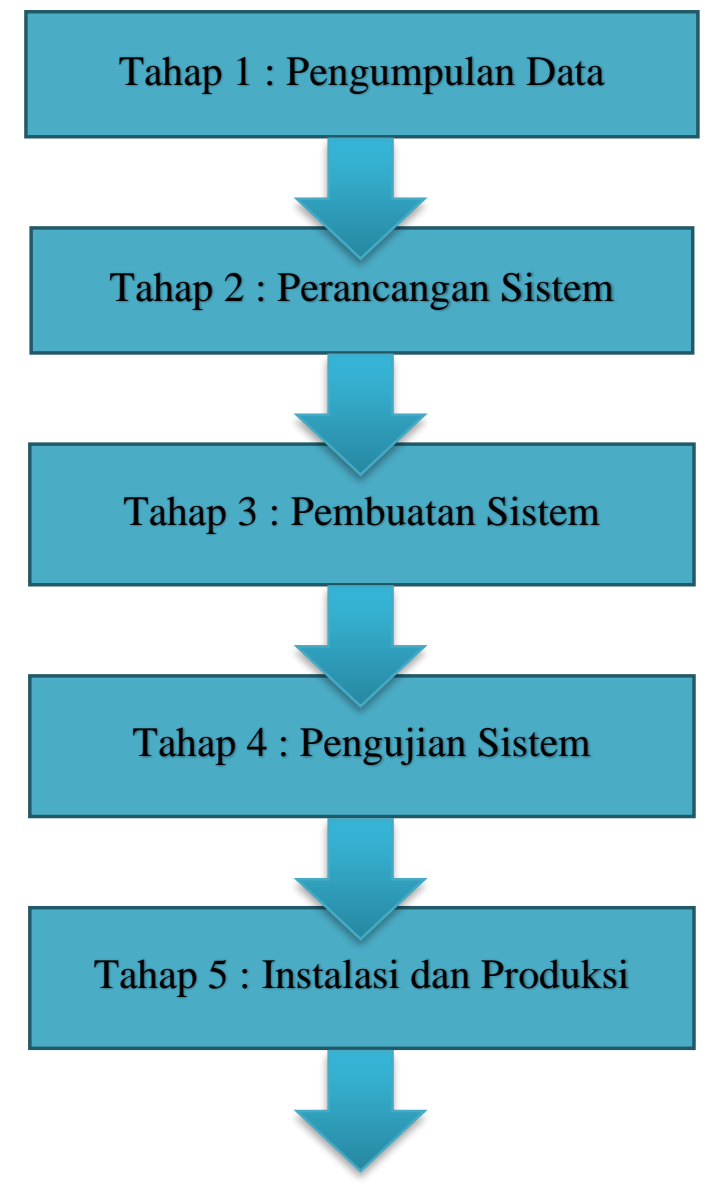




\section{Tahap 6 : Pembuatan Laporan \\ Perancangan Sistem}

Gambar 1. Tahapan Penelitian

Tahap pertama, peneliti melakukan wawancara dengan pihak-pihak terkait dengan kasus yang ada. Peneliti meneliti lebih dalam di bagian teknologi informasi. Tujuan wawancara ini adalah memperoleh data yang peneliti butuhkan untuk merancang sistem yang dibutuhkan di Bakesbangpol. Pada tahap merancang sistem, peneliti menggunakan metode perancangan Agile. Metode ini peneliti gunakan karena peneliti membutuhkan feedback dari pengguna untuk membangun sistem ini karena sistem akan digunakan dalam jangka waktu yang lama. Peneliti menggambarkan kebutuhan pengguna yang diperoleh pada tahap pertama dalam diagram-diagram. Diagram-diagram yang peneliti gunakan adalah Use Case Diagram, Activity Diagram, Sequence Diagram dan Class Diagram. Untuk informasi lebih lengkap, peneliti akan membahas tahap ini di sub bab metode perancangan sistem. Tahap ketiga adalah pembuatan sistem. Dari diagram-diagram yang sudah dibuat pada tahap kedua, peneliti membangun sistem yang dibutuhkan pihak Bakesbangpol. Tahap ini akan dijelaskan lebih lanjut pada bab hasil dan pembahasan. Dalam tahap yang keempat, sistem yang telah peneliti buat akan diuji oleh pihak Diskominfo. Jika sistem yang dibuat sudah sesuai dengan kebutuhan pihak Bakesbangpol maka peneliti melanjutkan tahap penelitian instalasi dan produksi. Akan tetapi, jika sistem tersebut belum sesuai dengan kebutuhan pihak Bakesbangpol maka peneliti akan memperbaiki lagi sistem tersebut. Di tahap kelima, peneliti Bersama pihak Diskominfo akan melakukan instalasi dan produksi terhadap sistem yang akan digunakan. Tahap ini akan dibahas lebih mendalam dalam bab hasil dan pembahasan. Di dalam tahap yang keenam, peneliti membuat laporan mengenai sistem yang sudah diproduksi. Laporan ini berisi tentang masalah yang dihadapi pihak Bakesbangpol dan upaya penyelesaiannya. Laporan ini juga berisikan informasi mengenai sistem yang telah dibuat dan diproduksi. Demikianlah enam tahap penelitian yang dilakukan peneliti. Mulai dari tahap pertama hingga tahap terakhir, peneliti melakukan tahapan tersebut sambil berkonsultasi dengan Bapak Budi Haryanto selaku penanggung jawab peneliti dan Bapak Augie David Manuputty selaku pembimbing peneliti.

\subsection{System Design}

Seperti yang telah disampaikan sebelumnya, metode perancangan sistem yang digunakan untuk membangun sistem ini adalah Agile. Agile adalah metodologi perancangan sistem yang bersifat iteratif dengan lebih berfokus pada kolaborasi. Dalam pembuatan sistem, programmer menggunakan dokumen formal yang terbatas dan tepat. Programmer akan menanggapi perubahan pada sistem sesuai dengan kebutuhan pengguna. [16] Tahapan metode Agile yaitu tahap specification, 
Vol. 2, No. 1, March 2020

p-ISSN: 2656-5935 http://journal-isi.org/index.php/isi

e-ISSN: 2656-4882

design, development, testing dan kembali ke tahap awal atau specification jika aplikasi masih memerlukan penyempurnaan. Berikut ini adalah gambar tahapan Agile.

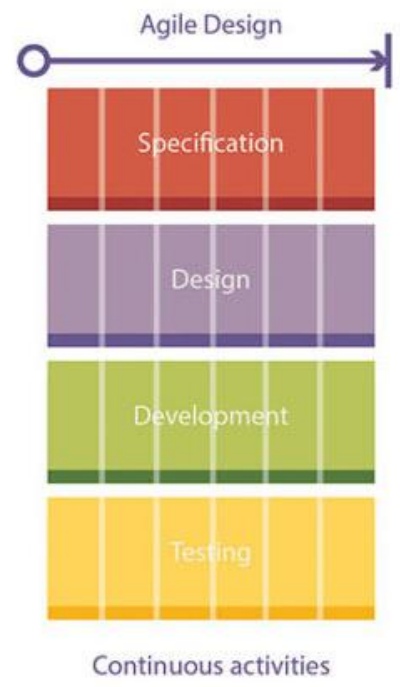

Gambar 2. Tahapan Agile [17]

Tahap pertama adalah specification. Pada tahap ini, peneliti melakukan wawancara dengan beberapa pihak Bakesbangpol, seperti operator dan sekretariat. Tujuan dari wawancara ini untuk mendapatkan informasi mengenai permasalahan dan kebutuhan pihak Bakesbangpol serta alur proses bisnis di Bakesbangpol. Selain itu, peneliti juga menggunakan data sekunder yang diberikan oleh pihak Bakesbangpol yang mendukung peneliti dalam membuat sistem. Selanjutnya pada tahap design, peneliti memetakan kebutuhan pengguna tersebut ke dalam Use Case Diagram, Activity Diagram, dan Class Diagram. Di tahap ketiga yaitu development, peneliti melakukan coding sesuai dengan kebutuhan yang sudah dipetakan pada tahap specification. Setelah program selesai dibuat, dilakukan pengujian oleh Bapak Budi terhadap aplikasi yang telah dibuat. Dalam kasus peneliti, peneliti mendapat feedback untuk memperbaiki aplikasi yang telah dibuat. Oleh karena itu peneliti kembali melakukan tahap awal yaitu specification. Peneliti mencatat feedback dan kebutuhan baru pengguna terhadap aplikasi tersebut. Selanjutnya, peneliti memetakan kembali kebutuhan baru pengguna. Peneliti merancang ulang struktur database untuk memenuhi proses bisnis sistem. Ini adalah tahap design. Setelah itu, peneliti melanjutkan ke tahap development. Peneliti kembali melakukan coding untuk memenuhi kebutuhan pengguna. Setelah selesai melakukan coding, peneliti melakukan pengujian dengan menggunakan White Box Testing. Selanjutnya, pengujian aplikasi dilanjutkan oleh Bapak Budi. Keputusan terakhir dari beliau adalah beliau menerima aplikasi tersebut. 


\section{RESULTS AND DISCUSSION}

Peneliti menggunakan diagram-diagram untuk memetakan kebutuhankebutuhan yang ada. Untuk memetakan secara garis besar seluruh kebutuhan yang ada, peneliti menggunakan Use Case Diagram. Dalam Use Case Diagram, peneliti menjelaskan sistem ini mendukung 3 level pengguna yaitu administrator, operator dan pemohon. Ketiga level pengguna tersebut harus login dulu untuk dapat melakukan proses bisnis lainnya sesuai dengan level pengguna, terkecuali proses bisnis registrasi dan ubah kata sandi. Seperti yang digambarkan di gambar 3. Pada proses bisnis kelola permohonan, berisikan data permohonan kerja praktek, pengambilan data dan survei. Selain itu, terdapat juga aktivitas pembuatan permohonan baru dan cek data input pemohon. Administrator dan operator dapat mengubah data permohonan seluruh pemohon, dan terdapat batasan data yang dapat diubah. Data yang dapat diubah adalah status permohonan pemohon dan catatan untuk memberikan informasi kepada pemohon terkait permohonan yang diajukan oleh pemohon. Sedangkan pemohon, hanya memiliki hak akses untuk dapat mengubah data yang pemohon bersangkutan buat dan dapat mengubahnya selama status permohonan "BELUM DIPERIKSA". Untuk data dalam permohonan yang pemohon ajukan dan tidak ada di dalam database akan dicek oleh operator atau administrator lebih dulu. Pengecekan ini peneliti beri nama "cek data inputan pemohon". Apabila data yang diberikan pemohon tersebut diperbolehkan atau disetujui oleh operator atau administrator, maka data dapat digunakan dalam permohonan yang telah dibuat. Selanjutnya adalah proses bisnis kelola informasi bantuan. Proses bisnis ini dilakukan untuk mengolah informasi-informasi yang berkaitan dengan sistem ini, seperti melihat informasi bantuan, mengubah informasi bantuan, hapus informasi bantuan serta menambahkan informasi bantuan. Proses bisnis ini dapat dilakukan oleh administrator, operator ataupun pemohon. Perbedaannya, administrator dan operator dapat melihat, mengubah, menghapus, serta tambah informasi bantuan, sedangkan pemohon hanya dapat melihat informasi bantuan saja. Terdapat juga proses bisnis kelola panduan. Proses bisnis ini dilakukan untuk mengolah informasi-informasi panduan, Pada proses bisnis ini, administrator dan operator dapat mengubah, mengunduh, menghapus dan menambahkan informasi panduan. Pemohon hanya dapat mengunduh file panduan. Proses bisnis selanjutnya adalah kelola pengguna. Kelola pengguna yaitu proses bisnis untuk mengolah data pengguna, seperti nama, nomor telepon dan alamat tinggal. Proses bisnis ini hanya dapat dilakukan oleh administrator. Proses bisnis laporan, hanya dapat dilakukan oleh administrator dan operator. Pada proses bisnis ini, administrator atau operator dapat melihat informasi selama kurun waktu yang dipilih. Informasi yang disediakan berkaitan dengan organisasi, pekerjaan, fakultas, program studi, lokasi penelitian dan status permohonan dari seluruh permohonan yang telah dibuat. Proses bisnis kelola data pendukung, hanya dapat dilakukan oleh administrator dan operator. Proses bisnis ini berupa kelola informasi berkaitan dengan informasi pendukung, seperti pekerjaan, organisasi, fakultas, program studi dan lokasi penelitian. Administrator dan operator dapat 
Vol. 2, No. 1, March 2020

p-ISSN: 2656-5935 http://journal-isi.org/index.php/isi

e-ISSN: 2656-4882

melihat, mengubah, menghapus dan menambahkan informasi tersebut. Informasi yang ada di data pendukung digunakan di bagian pilihan, seperti pilih jenis pekerjaan dan pilih nama fakultas. Proses bisnis yang terakhir adalah lihat histori. Proses bisnis ini hanya dapat dilakukan oleh administrator. Administrator dapat melihat segala aktivitas yang dilakukan oleh seluruh pengguna. Hal ini dilakukan agar administrator dapat memberikan tindakan terkait jika terdapat akitivitas yang dapat mengancam keamanan sistem. Selain itu, administrator juga dapat memperbaiki kerusakan yang terjadi dengan melihat aktivitas yang pengguna lakukan.

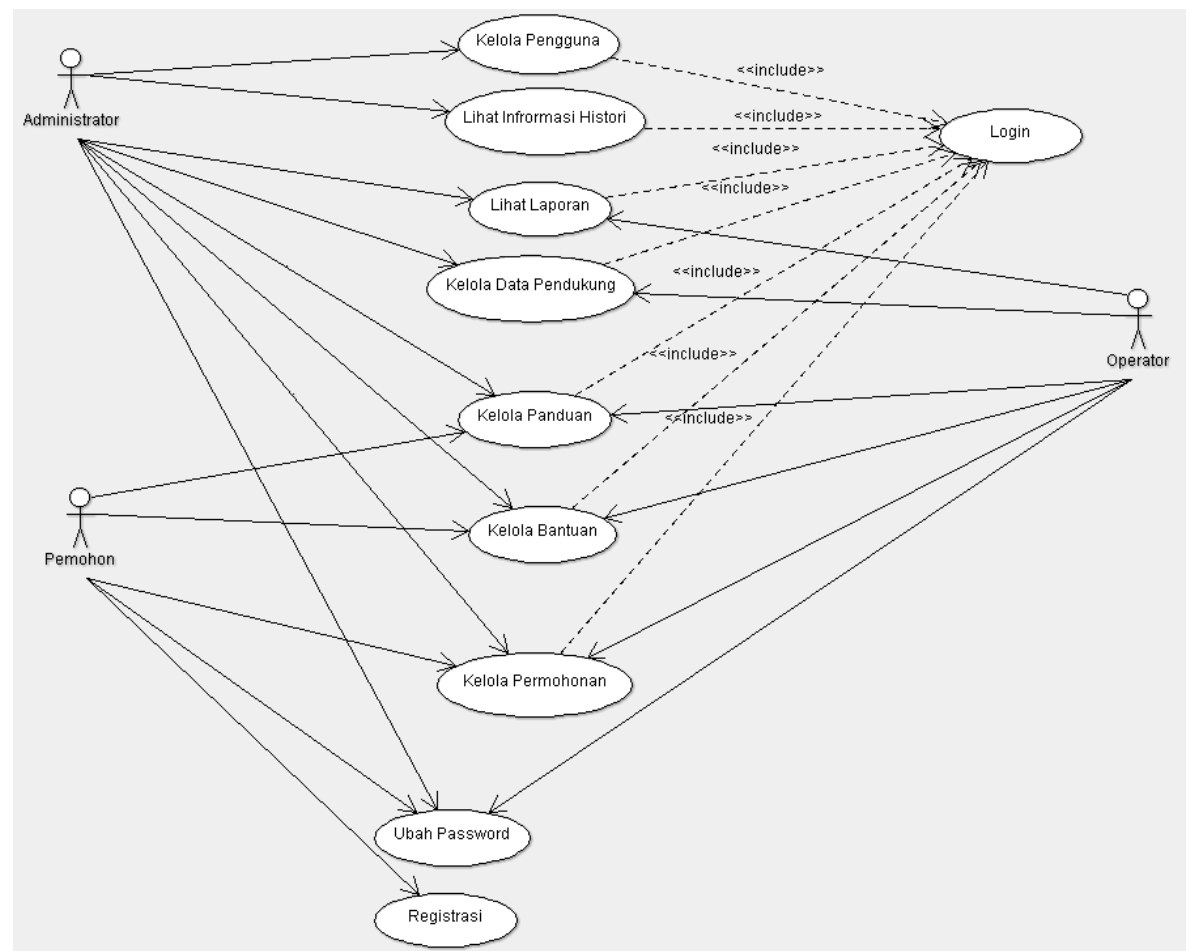

Gambar 3. Use Case Diagram SIPPP

Aktivitas selanjutnya adalah lihat informasi permohonan. Aktivitas ini dilakukan untuk melihat permohonan yang dibuat. Permohonan tersebut terdiri dari semua jenis permohonan baik kerja praktek, pengambilan data ataupun survei. Aktivitas ini dapat dilakukan oleh semua level pengguna. 
Vol. 2, No. 1, March 2020

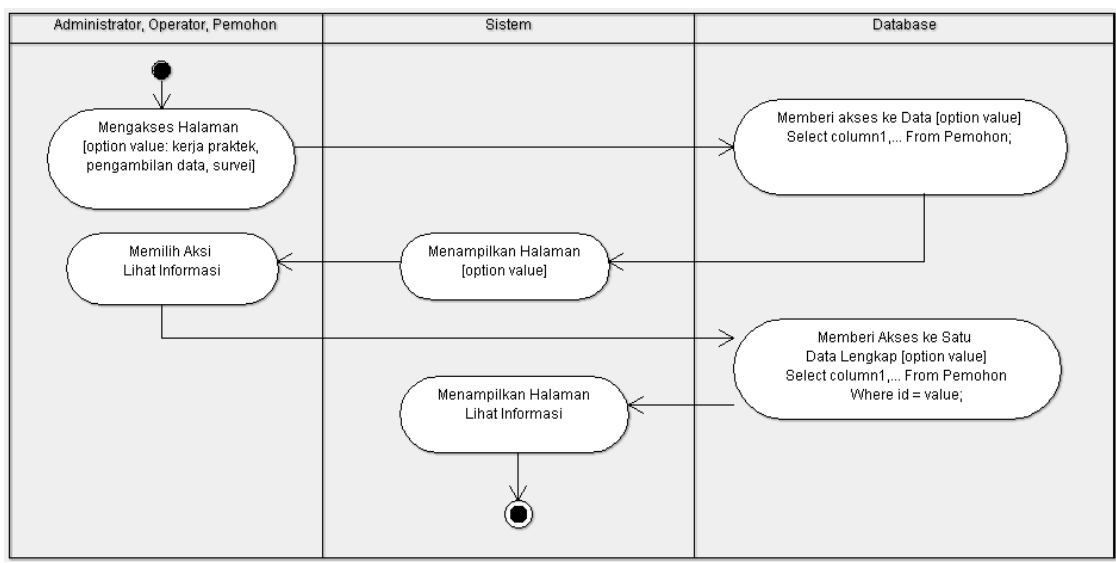

Gambar 4. Activity Diagram Lihat Informasi Permohonan

Ubah informasi permohonan adalah aktivitas untuk mengubah informasi suatu permohonan. Aktivitas ini dapat dilakukan oleh semua level pengguna. Perbedaan terdapat di bagian informasi yang dapat diubah oleh pemohon dengan informasi yang dapat diubah operator atau administrator. Informasi yang dapat diubah pemohon adalah semua informasi saat membuat permohonan, sedangkan administrator atau operator hanya dapat mengubah informasi sebagai tanggapan atas permohonan yang diajukan. Aktivitas ini hanya dapat dilakukan oleh pemohon saat status permohonan adalah belum diterima. Namun, bagi administrator atau operator, perubahan informasi dapat dilakukan setiap waktu saat dibutuhkan.

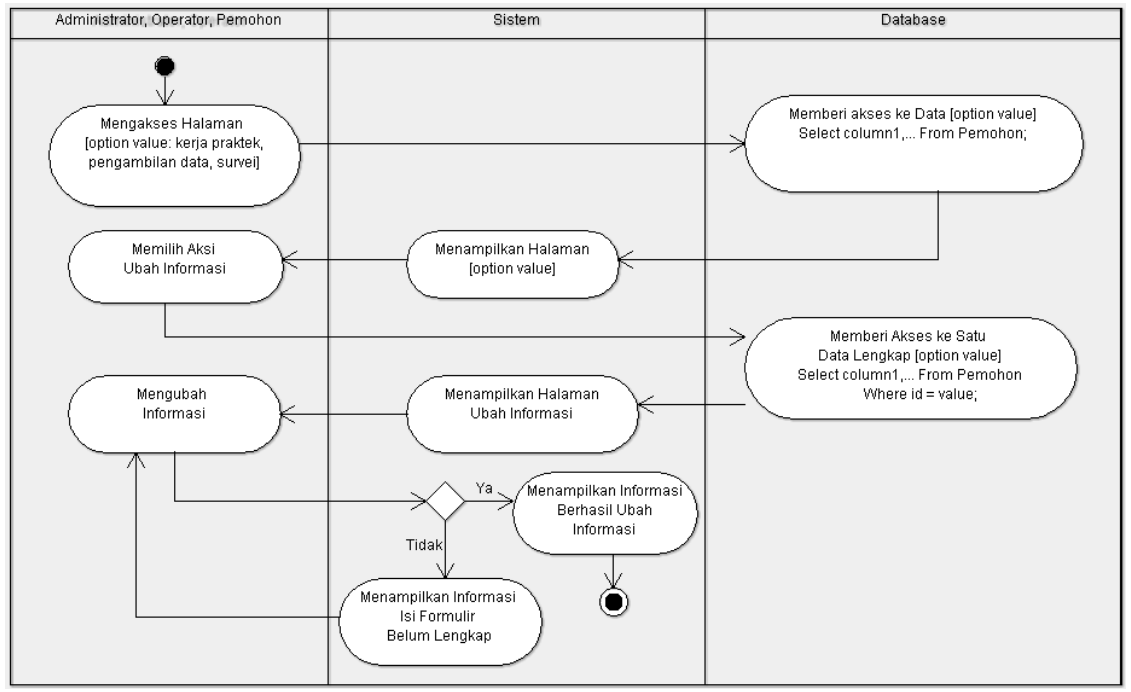

Gambar 5. Activity Diagram Ubah Informasi Permohonan 
Vol. 2, No. 1, March 2020

p-ISSN: 2656-5935

http://journal-isi.org/index.php/isi

e-ISSN: 2656-4882

Tambah permohonan adalah aktivitas untuk membuat sebuah permohonan. Permohonan dapat berjenis permohonan kerja praktek, pengambilan data ataupun survei. Tambah permohonan dapat dilakukan oleh semua level pengguna.

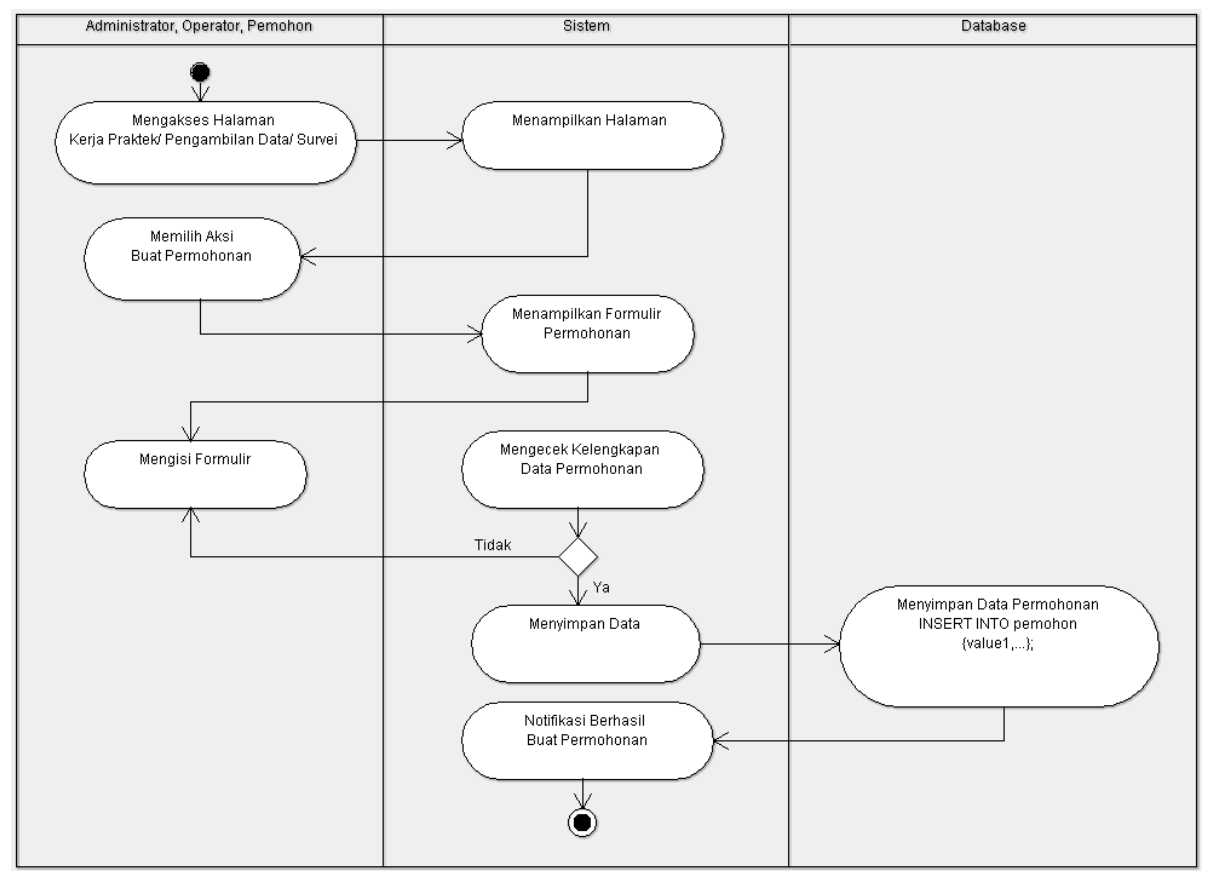

Gambar 6. Activity Diagram Tambah Permohonan

Peneliti menggambarkan alur data dalam sistem menggunakan Diagram Class. Dalam diagram ini, terdapat 3 jenis kelas dan 1 database. Kelas tersebut yaitu boundary class, controller class dan entity class. Sistem ini menampung 27 boundary class, 5 control class dan 12 entity class. Beberapa boundary class memiliki control class yang sama. Sebagai contoh, boundary class lihat informasi permohonan, lihat informasi bantuan, dan lihat informasi panduan menggunakan controller class yang sama yaitu lihat informasi. Untuk controller class, satu controller class digunakan oleh beberapa entity class, seperti controller class lihat informasi. Controller class lihat informasi digunakan oleh entity class permohonan, data inputan pemohon, bantuan, panduan, pengguna, organisasi, pekerjaan, fakultas, program studi, lokasi penelitian dan histori. Data-data yang ada di setiap entity class tercakup dalam database SIPPP. 
Vol. 2, No. 1, March 2020

p-ISSN: 2656-5935 http://journal-isi.org/index.php/isi e-ISSN: 2656-4882

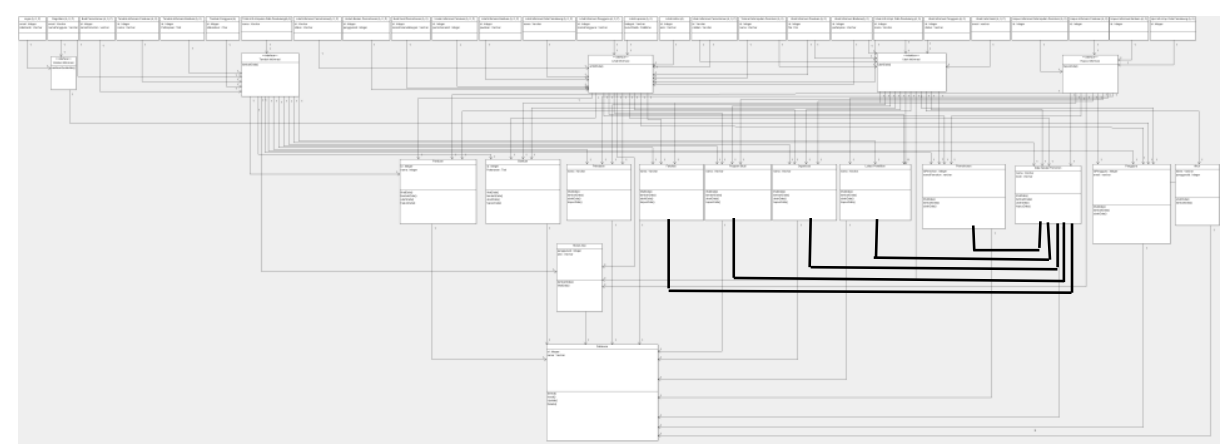

Gambar 7. Class Diagram SIPPP

Setelah perancangan sistem selesai dibuat, peneliti membuat sistem sesuai dengan pemetaan kebutuhan dalam diagram-diagram yang telah peneliti buat. Namun, seiring pembuatan sistem ada beberapa hal yang peneliti modifikasi untuk menjaga keamanan sistem dan memudahkan penggunaan sistem bagi pengguna. Berikut ini adalah beberapa tampilan dari sistem yang telah peneliti buat. Tampilan halaman lihat informasi permohonan mencakup aktivitas lihat informasi kerja praktek, lihat informasi pengambilan data dan lihat informasi survei. Halaman ini menampilkan informasi permohonan yang telah dibuat. Dari halaman ini, pengguna dapat mengetahui informasi yang berkaitan dengan permohonan.

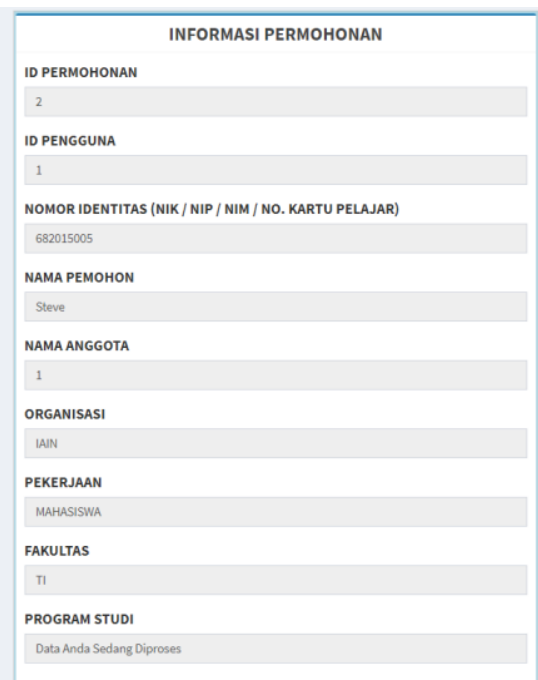

Gambar 8. Tampilan Halaman Lihat Informasi Permohonan

Tampilan halaman ubah informasi permohonan digunakan oleh pengguna untuk mengubah informasi permohonan. Terdapat dua jenis tampilan untuk halaman ubah informasi permohonan, yaitu tampilan untuk pemohon dan tampilan untuk administrator atau operator. Perbedaan tampilan terdapat di kolom informasi yang 
Vol. 2, No. 1, March 2020

dapat diubah informasinya dan yang tidak dapat diubah informasinya. Untuk tampilan administrator, kolom informasi yang dapat diubah informasinya diberi warna putih, sedangkan informasi yang tidak dapat diubah diberi warna biru muda, seperti pada gambar.

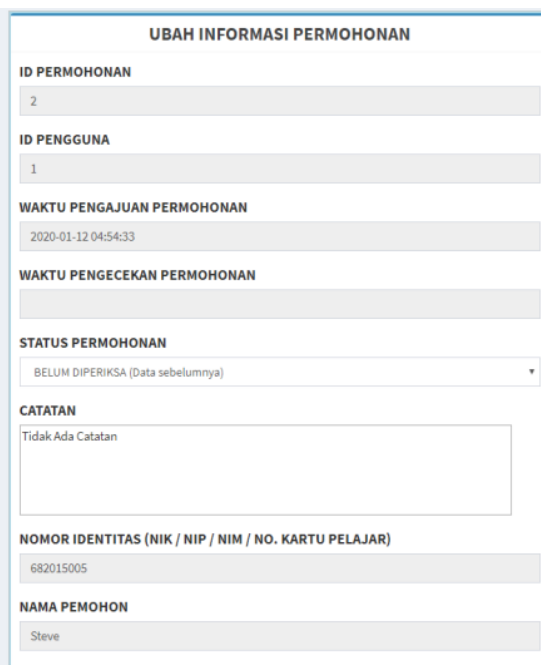

Gambar 9. Tampilan Ubah Informasi Permohonan Untuk Administrator Dan Operator

Tampilan ini merupakan tampilan halaman ubah informasi permohonan untuk pemohon. Nampak perbedaan warna kolom informasi untuk informasi yang dapat oleh administrator atau operator dengan informasi yang dapat diubah oleh pemohon. Begitu pula perbedaan warna kolom informasi untuk informasi yang tidak dapat diubah. 
Vol. 2, No. 1, March 2020

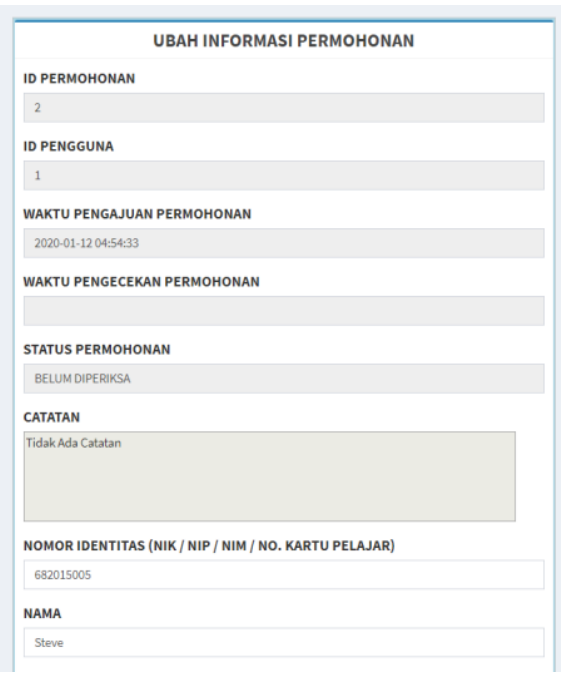

Gambar 10. Tampilan Halaman Ubah Informasi Permohonan Untuk Pemohon

Ini adalah tampilan untuk halaman tambah permohonan. Tampilan untuk halaman ini sama untuk setiap level pengguna.

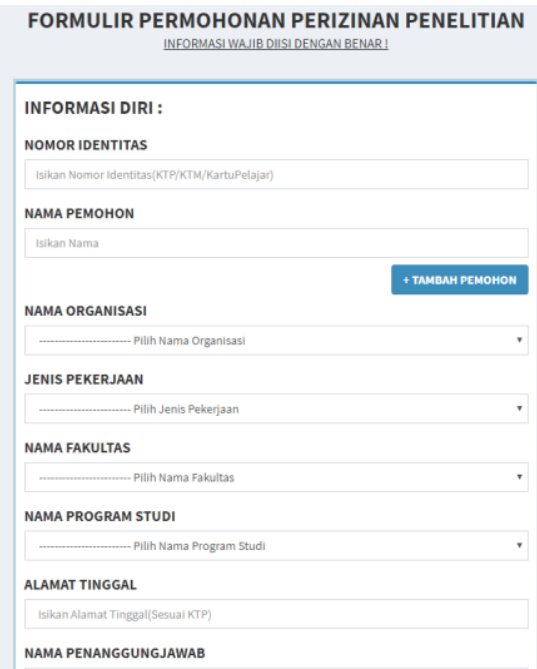

Gambar 11. Tampilan Halaman Tambah Permohonan

Peneliti melakukan pengujian terhadap aplikasi dengan metode White Box Testing. White Box Testing adalah jenis pengujian aplikasi dengan memperhatikan algoritma sistem. [18] Dalam tahap ini, peneliti menemukan beberapa bug pada aplikasi, seperti tidak dapat simpan informasi permohonan, tidak dapat ubah informasi permohonan. Hal ini dikarenakan beberapa alasan, seperti kesalahan 
Vol. 2, No. 1, March 2020

p-ISSN: 2656-5935 http://journal-isi.org/index.php/isi e-ISSN: 2656-4882

peneliti dalam menggunakan operator logika $(!,<,>)$ dan lainnya. Namun peneliti sudah memperbaiki bug yang didapati pada proses pengujian. Untuk hasil akhir pengujian, semua proses dinyatakan berhasil. Berikut adalah proses yang peneliti tes.

Tabel 1. Hasil Pengujian Sistem dengan White Box Testing

\begin{tabular}{|l|l|l|l|}
\hline Fitur & $\begin{array}{c}\text { Cyclom } \\
\text { atic } \\
\text { Comple } \\
\text { xity }\end{array}$ & $\begin{array}{c}\text { Independe } \\
\text { nt Path }\end{array}$ & $\begin{array}{c}\text { Hasil } \\
\text { Penguian }\end{array}$ \\
\hline Tambah Permohonan & & & Berhasil \\
\hline Lihat Permohonan & & & Berhasil \\
\hline Ubah Permohonan & & & Berhasil \\
\hline Buat Surat Permohonan & & & Berhasil \\
\hline Lihat Surat Permohonan & & & Berhasil \\
\hline Unduh Berkas Permohonan & & & Berhasil \\
\hline Unduh Panduan & & & Berhasil \\
\hline Ubah Informasi Panduan & & & Berhasil \\
\hline Hapus Panduan & & & Berhasil \\
\hline Tambah Panduan & & & Berhasil \\
\hline Lihat Bantuan & & & Berhasil \\
\hline Ubah Bantuan & & & Berhasil \\
\hline Hapus Bantuan & & & Berhasil \\
\hline Tambah Bantuan & & & Berhasil \\
\hline Lihat Data Pendukung & & & Berhasil \\
\hline Ubah Data Pendukung & & & Berhasil \\
\hline Hapus Data Pendukung & & & Berhasil \\
\hline Tambah Data Pendukung & & & Berhasil \\
\hline Terima Data Inputan & & & Berhasil \\
\hline Hapus Data Inputan & & & \\
\hline Lihat Laporan & & & \\
\hline Lihat Histori & & & \\
\hline Lihat Informasi Pengguna & & & \\
\hline Ubah Informasi Pengguna & & & \\
\hline Tambah Pengguna & & & \\
\hline
\end{tabular}

Selanjutnya pada tahap implementasi dan produksi, peneliti belum dapat melakukan hal tersebut. Untuk hal tersebut, peneliti akan berdiskusi lebih lanjut dengan pihak Diskominfo mengenai pengimplementasian dan produksi sistem ini. Tahap terakhir yaitu pembuatan laporan pembuatan sistem. Peneliti membuat dokumentasi sistem untuk diberikan kepada pihak Diskominfo dan Bakesbangpol. Dokumen sistem yang peneliti buat berupa Tugas Akhir peneliti. 


\section{CONCLUSION}

Teknologi merupakan alat yang digunakan untuk mendukung pekerjaan manusia. Dalam pemerintahan Kota Salatiga, terkhusus di bagian pengelolaan permohonan Penelitian diperlukan teknologi untuk mengatasi permasalahan yang ada. Operator menghadapi permasalahan dalam melakukan record untuk pemohon berkelompok dan dalam pembuatan laporan mengenai permohonan tersebut. Solusi yang digunakan untuk mengatasi permasalahan-permasalahan tersebut adalah membuat website untuk membantu operator dalam melakukan record data untuk pemohon berkelompok dan dalam membuat laporan. Website juga digunakan untuk mendukung operator dalam pengelolaan permohonan penelitian yang diajukan. Peneliti menggunakan Agile sebagai metode perancangan sistem dan Laravel sebagai framework pembuatan website.

\section{REFERENCES}

[1] Peraturan Walikota Salatiga Nomor 52 Tahun 2016 tentang Kedudukan, Susunan Organisasi, Tugas dan Fungsi serta Tata Kerja Badan Kesatuan Bangsa dan Politik., Salatiga: Sekretariat Daerah, 2016.

[2] W. W. Winamo, Sistem Informasi Manajemen, 3rd ed., Yogyakarta: UPP STIM YKPN, 2017.

[3] P. Christian, Ed., Sistem Informasi Bisnis, Yogyakarta: Andi, 2019.

[4] Sedarmayanti, Tata Kearsipan, Bandung: CV Mandar Maju, 2018.

[5] Al-Khawarizmi and D. Averroes, "NegaraHukum.com," 9 Januari 2013. [Online]. Available: http://www.negarahukum.com/hukum/pengertianperizinan.html. [Accessed 12 Agustus 2019].

[6] A. Anggraini, "About Us: Scribd Incorporation," Scribd Incorporation, 1 Maret $2017 . \quad$ [Online]. Available: https://www.scribd.com/document/340618438/Pengertian-PerizinanMenurut-Para-Ahli. [Accessed 12 Agustus 2019].

[7] R. Abdulloh, 7 in 1 Pemrograman Web untuk Pemula, Jakarta: PT Elex Media Komputindo, 2018.

[8] B. Syahid, "18 Pengertian Website Menurut Para Ahli - Sejarah, Jenis \& Manfaat," $21 \quad$ Februari 2019. [Online]. Available: https://www.gurupendidikan.co.id/pengertian-website/. [Accessed 12 Agustus 2019].

[9] Y. Yudhanto and H. A. Prasetyo, Mudah Menguasai Framework Laravel, Jakarta: Gramedia, 2019.

[10] H. Sulistiono, Coding Mudah dengan CodeIgniter, JQuery, Bootstrap, Datatable, Jakarta: PT Elex Media Komputindo, 2019.

[11] P. Christian, Bootstrap CSS Framework, Yogyakarta: Andi, 2019. 
[12] E. D. Lestari, Ed., Metode Penelitian Kualitatif, Sukabumi: CV Jejak, 2018.

[13] M. Fitrah and Luthfiyah, Metodologi Penelitian, Sukabumi: CV Jejak, 2018.

[14] A. A. Muhlisian, "Analisis Kesalahan Terjemahan Bahasa Jepang Yang Terdapat Dalam Karya Ilmiah Mahasiswa S2," Universitas Pendidikan Indonesia, vol. 2, no. 1, pp. 31-32, 2013.

[15] E. D. Lestari, Ed., Metodologi Penelitian Kualitatif, Sukabumi: CV Jejak, 2018.

[16] I. K. Raharjana, Pengembangan Sistem Informasi Menggunakan Metodologi Agile, Yogyakarta: Deepublish, 2017.

[17] A. O. Kiss, "How to integrate design into your agile process?," 19 Oktober 2016. [Online]. Available: https://uxstudioteam.com/ux-blog/agile-designprocess/. [Accessed 2 Maret 2020].

[18] V. John and H. Done, Principles and Practice of Software Testing, India : Educreation Publishing, 2018.

[19] W. W. Winarmo, Sistem Informasi Manajemen, 3rd ed., Yogyakarta: UPP STIM YKPN, 2017. 